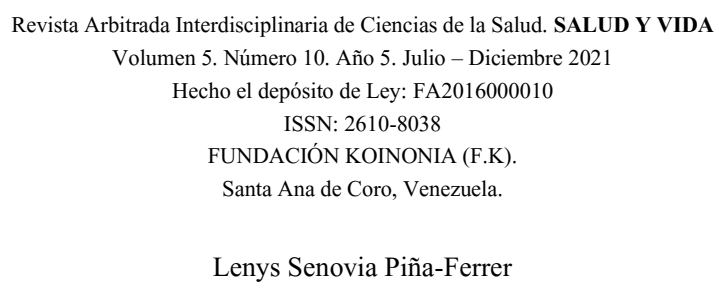

http://dx.doi.org/10.35381/s.v.v5i10.1421

\title{
Medidas previsivas postpandemia
}

El hombre es parte de la compleja estructura de la vida, en la que imprime el deseo de garantizar su existencia y las oportunidades adecuadas de desarrollo, con patrones moldeados por el deseo o la ambición. En ese sentido, las actividades humanas están alterando los ecosistemas y provocando pérdidas que no se veían en décadas. Hoy en día, un planeta devastado sigue albergando vida, pero con recursos limitados, capacidad de carga limitada y en la lucha entre la resistencia de la naturaleza y el poder transformador del hombre, las personas no siempre pueden ganar.

En ese sentido, el dolor de la pandemia de COVID19, un evento que ciertamente ha marcado nuestro tiempo, perdurará mucho después de que el virus esté en remisión. Cuando termine la crisis inmediata, muchos sufrirán pérdidas inimaginables, otras personas perderán a sus seres queridos, muchas estarán desempleadas y posiblemente sin hogar, y varios cientos de millones de personas experimentarán el sufrimiento y la soledad del aislamiento social.

Sobre lo expuesto es importante agregar esas y otras consecuencias que ha traído consigo los efectos de la pandemia, a pesar de que las campañas han abarrotado las redes y aun lo siguen haciendo, la sociedad no ha terminado de entender la magnitud y la gravedad de la misma. Ante ello surge la necesidad de que nosotros como seres humanos pensantes seamos los que demos el ejemplo de prevención con las respectivas medidas.

Los gobiernos han hecho los esfuerzos que les corresponde (unos más que otros) en cuanto a vacunación, jornadas de sensibilización sobre el distanciamiento social, lavado de manos, uso correcto del tapabocas, programas radiales y televisivos, pero lamentablemente eso no es efectivo si las personas no toman conciencia, aun con la cantidad de víctimas producto de la pandemia, cifras si se quiere elevadísimas, podemos observar, escuchar personas resistentes a la aplicabilidad de dichas medidas. 
Sin embargo, sobre lo antes descrito, también tenemos la capacidad de elegir y ganar. Cuando salgamos de este trauma colectivo podemos decidir volver a la vieja trayectoria o aprender de la experiencia para tomar diferentes decisiones para el futuro. En fin "Todos estamos preocupados por combatir este virus" La decisión está en nuestras manos.

Dra. Lenys Senovia Piña-Ferrer

dralenysp@gmail.com

Instituto de Investigación y Estudios Avanzados Koinonía, Santa Ana de Coro Venezuela

https://orcid.org/0000-0002-9493-7499 